\title{
American Political Scientists on the Use of Force: Classifying the
}

\section{Concepts}

\author{
Darya Sukhovey ${ }^{1} \&$ Yana Gayvoronskaya ${ }^{1}$ \\ ${ }^{1}$ Law school, Far Eastern Federal University, Vladivostok, Russia \\ Correspondence: Darya Sukhovey, Law school, Far Eastern Federal University, Vladivostok, Russia. Tel: \\ 79-14-706-5409. E-mail: sumarusya@yandex.ru; yanavl@yandex.ru
}

Received: July 1, 2013 Accepted: July 29, 2014 Online Published: September 29, 2014

doi:10.5539/ass.v10n19p77 URL: http://dx.doi.org/10.5539/ass.v10n19p77

\begin{abstract}
This article argues that existing general typologies of the use of force concepts accepted by American political scientists do not correspond with the reality. The survey compares several distinctive approaches which are generally proposed to classify the ideas elaborated in American political circuits and comes to the conclusion that none of the mentioned approaches could be applied directly to the use of force issue due to numerous difficulties occur while drawing on existing classifications. The article proposes a new method for systematizing these American political theories which is based on two main criteria: scholars' attitude towards actual use of force and their perceptions of threats/challenges to national security. According to the newly introduced typology there are three major trends in American political thought on the issue: the first one consolidates those who support active and aggressive use of force (proponents of intervention or Interventionalists), the second one includes concepts of those authors who are not against the use of American forces abroad but stand on less aggressive positions (Conceptualists), and the third one unites those American political authors who insist that the US should use the force only in case of direct imminent attack on the American soil (Defenders).
\end{abstract}

Keywords: American political scientists, use of force, ideas systematization

\section{Introduction}

As we entered the XXI century it did not meet our expectations of peaceful and secure world. Military force prevails as a widely used tool of foreign policy and political bargaining: the number of local conflicts and interstates confrontations has not diminished but in fact is alarmingly increasing. Besides, informational technologies of the XXI century predetermine the fact that the aftermath of each conflict nowadays would be even more devastating and calamitous.

In this regards it is important to reveal the main tendencies in political behavior of the United States of America as currently Washington possesses military and technological domination in the world. As American political scientists closely cooperate with the US Government our reference to the interpretations of the use of force issue which are prevalent in the US scientific and political circles can help us to see the outlines of possible shifts in the Washington's policy.

In order to give a comprehensive description to those numerous ideas that exist in American political discourse on the issue it is extremely important to make the systematization of the most prominent theoretical tendencies.

American political experts' point of view on the use of force issue was not decided to become a main criterion of systematization; however there are typologies based on a compatible criterion which might be applied for the description of American political scientists' position on the problem of military enforcement: realism/idealism, conservatism/neo-conservatism and neo-isolationism. The convenience and effectiveness of these typologies would be examined below.

\section{Discussion}

The traditional for political science division into realism and idealism imposes significant constraints while this criterion of systematization is applied to the use of force concepts as long as it is more likely to cover general aspects than the specific ones. 
As it can be derived from the typology description realists are those who "a) view international policy separately from internal one; b) consider conflict to be the basis of states' behavior and therefore view international legislation and rules as having minimal impact on war prevention" (Rikhtik, 2004). Another distinct approach belongs to idealists, who consider that: "a) states are not the only actors on international arena; b) international cooperation is powerful method to avoid wars d) international organization, legislation and rules have a great impact on states as cooperation is a basis of state behavior (Rikhtik, 2004).

Therefore only appreciation or depreciation of the international cooperation by the representatives of these theoretical schools could be applied to the use of force issue directly. However this typology is rather vague and requires several additional theoretical implications for proper description of the full range of ideas about the use of force in US political science discourse due to several reasons:

1. This typology does not consider the fact that almost all authors who are proponents of active use of force in the international arena - and even those who do not speak in favor of international organizations - express their support for the international cooperation.

Also in this regards it is unclear what category R. Perle (2008), who consider that international organizations should serve the US interests, should be added to. He affirms that the US would use the resources of international organizations' pro domo sua. This position goes beyond the tradition of realism as it speaks in favor of impact of international organizations and does not reside within the pillars of idealism as well since it states that such cooperation is not the impetus to stop war.

2. Neither realism nor idealism makes a difference between the positions of those authors who consider that the use of force should be the last resort and of those who do not. This typology does not have any mechanism for this kind of differentiation; drawing such a distinction is crucial for a proper reflection of American political scientists' points of view, even though.

3. Proponents of less aggressive concepts of the use of force within the offshore balancing, selective engagement and balance of power will be either ignored by realism/idealism typology or equaled to those authors who support aggressive use of force approach, yet it is logically incorrect.

4. Authors who speak in favor of the use of force only within the frameworks of self-defense are completely ignored by the typology as this systematization does not have any mechanism which would describe the position of these authors. This case shows that such typology omits an important category while describing the use of force issue.

Thus, basing upon the abovementioned arguments we can see that realism/idealism typology is not sufficient to describe the ideas of the US scientists about the use of force problem.

While using another systematization of political points of view for describing the attitudes towards the use of force problems.- conservatism/neo-conservatism - we also come across certain obstacles.

As in the previous case conservatism/neo-conservatism systematization is also designed to describe mostly generic issues. M. N. Khanov clarifies that conservatism relating to the foreign policy is "achieving political goals through military methods" (Khanov, 2006).

Despite the fact that this typology is important, it poses certain difficulties while applied to the use of force concepts:

1. This typology does not consider the fact that the group of authors who are in favor of achieving political goals using military methods has additional internal division. Thus those authors who stay on the position that the use of force is a primary method and those who consider the use of force to be the last resort will be in the same "boat" of conservators. However it is important to make a distinction between their positions.

2. According to the conservatism criterion the proponents of a less aggressive approach to the use of force (those who support the balance of power, offshore balancing and selective engagement concepts) and those authors who are against intervention will be in the same group with authors who argue aggressive position on the use of force issue. It will be logically incorrect.

In accordance with the circumstances mentioned above it can be seen that conservatism typology cannot reflect the full range of the US scientist's approaches to the use of force issue.

Before examining neo-conservatism typology we have to define its essence. Francis Fukuyama in his book "America at the crossroads" underlines four main features which characterize neo-conservatists: 
- "A belief that the internal character of regimes matters and that foreign policy must reflect the deepest values of liberal democratic societies.

- A belief that American power has been and could be used for moral purposes, and that the United States needs to remain engaged in international affairs.

- A distrust of ambitious social engineering projects. The untoward consequences of ambitious efforts at social planning is a consistent theme in neoconservative thought that links the critique of Stalinism in the 1940s with The Public Interest's skepticism about the Great Society in the 1960s.

- And finally, skepticism about the legitimacy and effectiveness of international law and institutions to achieve either security or justice" (Fukuyama, 2005). The last position is also describes Russian political scientist P.U. Rahshmir who considers that neo-conservators "have great distrust to international organizations" (Rahshmir, 2007).

Though these criteria can be applied to the description of American political thinkers' ideas, we would face several points of controversy:

1. Authors who are in favor of aggressive use of force are speaking about the same ideas: regime change, preventive use of force, limited sovereignty. All these ideas are based on the assumption that a state that has irresponsible policy can be the object of military operation. Therefore almost all American political experts who argue aggressive use of force believe that internal character of regimes matters. However this criterion does not make any difference between real division inside group of those who argue necessity of aggressive use of force: it did not specify group of those who consider use of force to be the last resort and those who consider the use of force to be the primary political instrument.

2. All American political writers express their skepticism about effectiveness of international institutions. In accordance with fourth criterion (in accordance with Fukuyama's work) those authors who argue that international institutions are not needed at all will be considered to be neo-conservators along with authors who are sure that international institutions' reforms is a way out to improve legitimacy and efficiency. This approach does not reflect the situation correctly.

For example, C. Krauthammer (2003) advised to refuse from cooperation in the frames of fixed institutional system and insists on cooperation in flexible coalition of states with the same goals instead of ineffective UN and NATO. This approach does not correlate with J. Ikenberry position who proposes a strategy of rising UN effectiveness. In accordance with Fukuyama's criterion Ikenberry and Kauthammer will be in the same group neo-conservators.

Thus typology conservatism/neo-conservatism does not reflect real situation concerned use of force issue.

Classifications of American political concepts (for example division on liberal interventionalists and imperial unilateralists (Voitovskiy, Guzev, \& Solovyev, 2005) that are based on criterion of attitude towards unilateral and multilateral approach to cooperation also have variety of difficulties occur.

All American political scientists who are in favor of aggressive use of force consider that international cooperation is useful in the case of military operations. And unilateral approach is also recognized as necessary option in some cases.

For example proponent of active use of force S. Groves considers that "Going to war with allies by your side is preferable to going to war alone" (Groves, 2010).

Standing on the position of active force approach Richard Perle calls coalitions "important and useful, sometimes essential" (Perle, 2008).

Another proponent of aggressive use of force approach M. Boot proposes to diminish rising China influence by creating Asian NATO analog. According to his opinion old partners like Japan, Australia and new one - India and Singapore would be members of this new organization (Boot, 2005).

Thus upholders of active use of force position do not exclude international cooperation and therefore they cannot be named unilateralists.

On the opposite side those authors who support less aggressive approach towards use of force issue are speaking about unilateral operation if the situation requires it.

For example J. Steinberg and I. Daalder make recommendations to coordinate military actions with international community and core partners. (Steinberg \& Daalder, 2005). However the authors recognize US right to act unilaterally if the situation (in accordance with their opinion) requires it (Steinberg \& Daalder, 2005). 
The same opinion is shared by P. Feaver. The author points out that: "America should seek the legitimacy and burden-sharing of multilateral action wherever possible". However at the same time he outlines that "America should seek the legitimacy and burden-sharing of multilateral action wherever possible" (Feaver, 2012).

These examples have shown that division which is based only on approach to unilateral/multilateral attitude to use of force does not cover all peculiarities in American political science dispute on use of force issue.

Political science attempts to underline group of neo-isolationist in American political dispute. However there also some problems occur while usage this cluster.

1. The very term "neo-isolationist" reflects negative position of interventionalists towards this group. In accordance with this position not to use military force means isolation. However it does not correspond with real position of the group: in accordance with their opinion force should be used only in case of self-defense.

2. It is misunderstanding, who should be considered to be isolationists. For example Barry Posen is called neoisolationist by E. Voeten (Voeten, 2014). However despite B. Posen stays on the position that US should limit its engagement in military conflicts he argues the necessity to use preventive military operations in some cases (Posen, 2008). Therefore the author is not against military operations in general. At the same time authors who insist only on the position that the reason for use of force should be only protection from imminent and direct attack on American territory will also be called isolationists. Thus the term "isolationists" covers different positions without clear classifications: in one group will be those authors who are not against use of force in general and those who are against use of force except self-defense from direct attack on American ground.

Taking into consideration that none from existing concepts' classifications can offer proper description of ideas circulating in US political dispute on the use of force issue there is a need for proposing classification that would be based on criteria of attitude towards use of force problem.

The main criterion for group division is attitude towards use of force activity. Thus in accordance with this criterion there are three groups underlined: those who are in favor of active use of force abroad, those who are not against it but are speaking about less aggressive approach then first group and the third who are against military interventions abroad, except cases of direct attack.

First group of authors are proponents of active use of force abroad. We consider that the term that will reflect the main characteristics of this group is "interventionalists".

Interventionalists are speaking about the same categories: they argue necessity of preventive attacks, regime change and implementing system of limited sovereignty. limited sovereignty is an idea that a state might be attacked if US or international community would consider that this state behaves irresponsible inside its border.

Among intervantionalists who support abovementioned ideas are: J. Grygiel who consider that traditional notion of sovereignty undermines US security (2010), S. Sewell (2008), T. Owens (2009) J. Steinberg (2005-2006).

Despite the fact that interventionalists have the same position the group is internally divided by two subgroups: radicals and rationalists.

There are two main criteria for this division. The first criterion is attitude to paramountcy of the use of force. The first subgroup - radicals - is represented by authors who consider that the use of force should be remained to be the last resort and the second one consists of authors who do not limit the possibilities of the use of force incidents.

For example C. Krauthammer names $9 / 11$ to be a "war" (Krauthammer, 2001). Using this term the author has shown that force is not the last resort. The same position is shared by M. Boot who considers that US should be world policemen. (Boot, 2006) Therefore these authors do not limit cases when use of force can be applied.

One the opposite side J. Ikenberry argues that preventive strikes are necessary tool for observing order and legitimacy. However they should be used as a last instrument (Ikenberry, 2002). The same position belongs to J. Steinberg (2006).

As criterion of multilateral/unilateral attitude towards the use of force does not work an attitude to legitimacy can be named as the second adequate criterion for radical/rationalist division. This criterion allows to describe different approaches exist in American political science. Radicals stand on the position that the use of force is an national decision and opinion of other states should not be taken into consideration. Contrary to this opinion rationalists are speaking about legitimacy's importance. Under legitimacy they understand other countries' support of US-conducted military interventions. It worth noting that legitimacy does not equal to legality and means only other states agreement with military campaign (Sukhovey, 2013). 
Thus the group interventionalists are divided into radicals and rationalists in accordance with two criteria: attitude to use of force prominence and legitimacy.

The second group after interventionalists is a group of conceptualists: it includes position of those authors who are not against the use of force abroad however they insists on less aggressive strategies, for example balance of power, offshore balancing and selective engagement.

For example A. Krepinevich in his article "The Pentagon's wasting assets" proposes to refuse from direct intervention and support regional states in their fight with islamists. At the same time Washington should be ready to mobilize its military forces if regional states do not manage to solve security problems (Krepinevich, 2005).

Offshore balancing means locating US military forces out of the zone of interests and giving privilege to regional states to solve security problems. If a state which can change balance of power in the region appear US would return its military forces to the region and restore status quo. Authors who support this idea are J. Mearshimer (2002), and C. Layne (2002).

Selective engagement concept points out that US should refuse from active military operations abroad and start war campaigns only for purposes that important for national interest: rule of law observance, human rights protection, and fight against terrorism (Art, 2012).

Additionally to abovementioned authors J. Nye and his "Smart power concept" (2007) should be listed among conceptualists.

One more group which should be presented separately from interventionalists and conceptualists is group of authors who insist on the idea that the use of force should be applied only in the case of self-defense. It worth noting that this group of authors uses the notion "self-defense" in its narrow term: direct military attack. Therefore this group of authors is against military intervention. Thus the position of these authors towards the use of force differs from opinions of authors from two previous groups as they view intervention as a core political instrument. The most appropriate group name which would reflect conceptual characteristics is "Defenders" which is made up from "self-defense".

Defenders' ideas can be found in the works of J. Record (2006), W. Pfaff (2010), A. Bacevich (2009), I. Eland (2012), and T. Moor (2006).

Correctness of American political concepts' division on three main groups is also proved by additional criterion - threat/challenge perception.

Inreventionalists and conceptualists are close in their threat/challenge perception. However there are some differences in group's approaches.

1. Conceptualists criticize interventionalists' approach to terrorism threat. Conceptualists consider that notion "terrorism" means tactic and cannot be named to be a enemy or threat. Conceptualists name concrete terroristic organizations like Shahaab and Al Qaeda to be a threat to national security. This opinion is described by Keister T. (2008), Falkenrath R. (2010)' Boucek C. (2011), Harnisch C. (2010), Cirincione J. (2010), Phillips J. (2006).

Also conceptualists point out that there is not a good idea to pay great attention to terrorist threat and consider that terrorist's threat is rather exaggerated. For example this opinion is shared by M. Mondenblam (2006), J. Nye (2007) and J. Muller (2006).

2. Interventionalists underline more threats to US national security then conceptualists. Interventionalists also are pointing out the threats from failed and rogue states. For example this position can be found in the works of Korb L. (2009), Fontaine R., Exum A. (2011), Feinstein L., Slaughter A. (2011).

Defenders' position to threat/challenges to US national security fdiffers from interventionalists and conceptualists. Representatives of this group consider that none of military threats challenge US national security.

For example J. Raimondo points that US military primacy is unrivaled and therefore there are no outside threats to Washington (Raimondo, 2012).

J. Glaser notes that US military expanding does not have any connections with threats as there are none of them for US (Glaser, 2012).

The same position is also said by I. Eland who argue that US is creating new kinds of threats in order to take benefits. (Eland, 2008). 


\section{Conclusion}

Despite the fact that political science proposes several classifications of American political thought, none of them can by applied while describing American political scientists' position towards the use of force issue. This situation is induced by the fact that existing typologies are rather general and undetailed and do not reflect the whole range of theoretical implications and peculiarities in American political science.

Therefore it seems to be reasonable to introduce another classification, which would reflect all the tendencies that exist in American political discourse concerning the use of force. The new classification based on the criteria of American political experts' attitude towards the activity of the use of force issue and threats/challenges to the US national security strategy was presented in this article.

In accordance with this typology the first group includes intervention proponents, the second one consists of those who insist on less aggressive use of force strategies, and the third one unites those authors who are against the use of force except cases of a self-defense from imminent and direct military attack.

\section{References}

American grand strategy: Global security in 21st century. (2006). Retrieved from http://www.cfr.org/unitedstates/american-grand-strategy-global-security-21st-century-role-united-states-rush-transcript-federal-newsservice-inc/p10071

American idol: An interview with Andrew Bacevich. Retrieved from http://www.uscatholic.org/culture/war-andpeace/2009/06/american-idol

Art, R. (2012). Selective engagement after Bush. Retrieved from http://www.cnas.org/ files/documents/press/America's\%20Path\%20Press\%20Release\%20for\%20web\%20site.pdf

Boot, M. (2005). Project for a new Chinese century. Retrieved from http://www.weeklystandard.com/Content/ Public/Articles/000/000/006/149ugqci.asp?page $=3$

Boot, M. (2006). On American foreign policy. Retrieved from http://www.nytimes.com/ref/books/ 18discussion-rc.html

Boucek, C. (2011). Terrorist threat to the U.S. homeland - Al-Qaeda in the Arabian Peninsula. Retrieved from $\mathrm{http} / / /$ carnegieendowment.org/publications/index.cfm?fa=view\&id=42811\&solr_hilite

Cirincione, J. (2006). The failure of regime change. Retrieved from http://www.americanprogress.org/ issues/2006/10/failure_regime_change.html

Daalder, I., \& Steinberg, J. (2005) The Future of Preemption. Retrieved from http://www.the-american-interest. com/article.cfm?piece $=35$

Eland, I. (2012). Putting defense back into US defense policy. Retrieved from http://www.independent.org/ aboutus/person_detail.asp?id $=487$

Falkenrath, R., Cullom, S., \& Davis, K. (2010). Countering threats abroad and at home. Retrieved from http://www.cfr.org/national-security-and-defense/countering-threats-abroad-home/p22915

Feaver, P. (2012). American grand strategy at the crossroads: Leading from the front, leading from behind or not leading at all. Retrieved from http://www.cnas.org/files/documents/publications/CNAS_AmericasPath_ FontaineAndLord.pdf

Feinstein. L., \& Slaughter, A. (2004). Duty to prevent. Retrieved from http://www.foreignaffairs.com/articles/ 59540/lee-feinstein-and-anne-marie-slaughter/a-duty-to-prevent

Fontaine, R., \& Exum, A. (2011). On the knife's edge: Yemen's instability and the threat to American interests. Retrieved from http://www.cnas.org/node/3771

Fukuyama, F. (2005). America at the crossroads: Democracy, power, and the neoconservative legacy. Yale University press: New Haven and London.

Groves, S. (2010). The Interdependence of National Security and National Sovereignty. Retrieved from http://thf_media.s3.amazonaws.com/2010/pdf/AR10-03.pdf

Grygiel, J. (2010). Costs of respecting sovereignty. Retrieved from http://www.sais-jhu.edu/faculty/grygie/ docs/grygielorbis2010.pdf

Harnisch, C., \& Szrom, C. (2010). It's a war. Where's the strategy? Retrieved from http://www.criticalthreats.org/yemen/its-war-wheres-strategy 
House Committee on oversight and government reform "Smart power and the U.S. strategy for security in a post-9/11 world". (2007). Retrieved from https://house.resource.org/110/org.c-span.202136-1.raw.txt

Ikenberry, J. (2002) Foreign affairs. America's imperial ambition (Vol. 8, pp. 44-60).

Keister, T. (2008). Defining victory in Iraq. http://www.securityaffairs.org/issues/2008/15/keister.php

Khanov, M. N. (2006). US role and place in modern international relations in accordance with US political science authors'perception. Omsk.

Korb, L., \& Katulis, B. (2009). Meeting the challenges in Pakistan. Retrieved from $\mathrm{http} / / /$ www.americanprogress.org/issues/2009/05/pakistan_trip_report.html

Krauthammer, C. (2001). This is not crime, this is war. Retrieved from http://townhall.com/columnists/ charleskrauthammer/2001/09/12/this_is_not_crime,_this_is_war

Krauthammer, C. (2003). Absurd UN is trying to make America a laughingstock. Retrieved from $\mathrm{http}: / /$ jewishworldreview.com/cols/krauthammer022803.asp

Krepinevich, A. (2009). The Pentagon's wasting assets. Foreign Affairs, (4), 28.

Layne, C. (2002). Offshore Balancing Revisited. The Washington Quarterly, 25(2), 233-248. http://dx.doi.org/ $10.1162 / 01636600252820252$

Mearsheimer, J. (2002). Head and minds. The National Interest, (69), 13-16.

Moor, T. (2006). Leaving Iraq is not enough. Retrieved from http://www.antiwar.com/moore/?articleid=9624

Mueller, J. (n. d.). Is there still a terrorist threat? The myth of the omnipresent enemy. Retrieved from http://www.diplomatie.gouv.fr/fr/IMG/pdf/menaceterroriste_exageration.pdf

Perle, R. (2008). Coalition of the ineffectual. Retrieved from http://www.aei.org/article/foreign-and -defense-policy/regional/middle-east-and-north-africa/coalition-of-the-ineffectual/

Pfaff, W. (n. d.). Manufacturing insecurity. Retrieved from http://www.foreignaffairs.com/articles/66869/ william-pfaff/manufacturing-insecurity

Phillips, J. (2006). Heritage Lecture: The Evolving Al-Qaeda Threat. Retrieved from http://www.cfr.org/ terrorism/heritage-lecture-evolving-al-qaeda-threat/p10255

Posen, B. (2008). Grant strategy of restraint. Retrieved from http://www.polsci.wvu.edu/faculty/hauser/ PS591Q/Posen2_Testimony071508.pdf

Preventive force in US national security strategy. (2005). Retrieved from http://www.google.com/\#hl=en\&spell $=1 \& \mathrm{q}=$ preventive + use + of + force + brookings + institution $\& \mathrm{sa}=\mathrm{X} \& \mathrm{ei}=0 \mathrm{RV}-\mathrm{UMr} 5 \mathrm{FO}$-ii4gSL2IHABA\&ved $=0 \mathrm{C}$ BoQvwUoAA\&bav=on.2,or.r_gc.r_pw.\&fp=de8375fd2732ac73\&bpcl=35277026\&biw=1280\&bih=798

Rakhshmir, P. (2007). American conservators and conservative idea. Perm: Perm university.

Record, J. (2006). American way of war. Retrieved from http://www.cato.org/pubs/pas/pa577.pdf

Rikhtik, M. T. (2004). State's security in US Republican party's ideology and political practice. Nozhnii Novgorod.

Sewell, S. (2008). A strategy of conservation: American power and the international system. Retrieved from http://web.hks.harvard.edu/publications/workingpapers/citation.aspx?PubId=5842P.118

Stainberg, J. (2006). Force and legitimacy in the post 9/11 era: What principles should guide the United States. Retrieved from http://www.utexas.edu/lbj/faculty/steinberg/papers/20060621_steinberg.pdf

Steinberg, J., \& Daalder, I. (2005). Preventive war, a useful tool. Retrieved from http://www.brookings.edu/ opinions/2005/1204iraq_daalder.aspx

Sukhovey, D. (2013). Use of force legitimacy in American political dispute. Retrieved from http://idosi.org/wasj/wasj26(11)13/15.pdf

The Foreign fighter problem: A conference report. (2009). Retrieved from www.fpri.org/research/ nationalsecurity/foreignfighters

Voeten, E. (2011). Case for new isolationism?. Retrieved from http://themonkeycage.org/blog/2011/02/07/ the_case_for_a_new_isolationis/

Voitovskiy, F. G., Guzev, P. A., \& Solovyev E. G. (2005) From world order of empires to imperial world order. Moscow: scientific forum on international relations. 


\section{Copyrights}

Copyright for this article is retained by the author(s), with first publication rights granted to the journal.

This is an open-access article distributed under the terms and conditions of the Creative Commons Attribution license (http://creativecommons.org/licenses/by/3.0/). 